\title{
PATHOMORPHOLOGICAL RESPONSE TO Encephalitozoon cuniculi INFECTION IN CYCLOPHOSPHAMIDE-TREATED RABBITS
}

\author{
M. HORVÁTH, E. ŠVICKÝ, Z. ŠEVČ́́KOVÁ \\ Department of Pathological Anatomy, University of Veterinary Medicine, Košice, Slovak Republic
}

Received January 30, 1998

Accepted March 3, 1998

\begin{abstract}
Horváth M., E. Švický, Z. Sevčíková: Pathomorphological Response to Encephalitozoon cuniculi Infection in Cyclophosphamide-treated Rabbits. Acta vet. Brno 1998, 67: 37-42.

Microsporidia are emerging opportunistic pathogens in immunosuppressed hosts. We have studied the pathomorphological response of cyclophosphamide-treated rabbits with experimental encephalitozoonosis. Forty New Zealand rabbits were used in the experiment. Experimental rabbits were infected intraperitoneally (i.p.) with $5 \times 10^{7} \mathrm{E}$. cuniculi spores. Two weeks after E. cuniculi infection, animals were i.p. injected with cyclophosphamide (CY) of $50 \mathrm{mg} / \mathrm{kg}$ and then once weekly with a dose of $15 \mathrm{mg} / \mathrm{kg}$. Control animals were treated with either $E$. cuniculi or CY, whereas negative controls were left untreated. Rabbits were killed in week 12 after the beginning of the CY treatment. Lesions were found in the brain, liver and kidney of both $E$. cuniculi infected groups, but they were different. The lymphoplasmacytic lesions of immunocompetent rabbits were consistent with findings previously described in spontaneous encephalitozoonosis. CYimmunosuppressed animals formed almost exclusively granulomatous lesions and rich infiltration with eosinophils within granulomas was also involved. The occurrence of distinct types of lesions indicates that $\mathrm{CY}$ modifies the pathomorphological response to $E$. cuniculi probably via the failure of immune system.
\end{abstract}

Microsporidia, granulomatous inflammation, giant-multinucleated cells, lymphocytes

Encephalitozoon cuniculi is an obligate intracellular parasite of the phyllum Microspora. It is the causative agent of encephalitozoonosis in a wide variety of animal species. $E$. cuniculi is considered to be an important opportunistic pathogen in people with AIDS (Mertens et al. 1997). Immunocompetent rabbits naturally infected with $E$. cuniculi develop chronic, usually latent disease accompanied with extensive kidney fibrosis and granulomatous meningoencephalitis. Chronic encephalitozoonosis produces lesions mostly in brain and kidney (Levkut et al. 1993). The acute period is characterised by the involvement of lung, kidney, and liver (Cox et al. 1979). Hepatic lesions are frequently observed in animals inoculated with E. cuniculi per rectum (Wicher et al. 1991). Immunocompromised hosts develop disseminated and lethal E. cuniculi infection (Koudela et al. 1993).

Cyclophosphamide (CY) is an alkylating agent, a chemical derivate of mechloretamine (Cox et al. 1975). It has been traditionally used for therapy of neoplastic diseases (Colvin 1982). Several side effects of CY including mutagenicity, teratogenicity hepatotoxicity and pulmonary toxicity were shown (Lynch and Mc Cune 1997). Experimental studies demonstrated that $\mathrm{CY}$ caused immunosuppression by its mitostatic activity on lymphoid tissue (Ladics and Loveless 1994) and myeloablative effect on bone marrow in rodents (Binta et al. 1996 ).

The objective of this work was to study the pathomorphological response to E. cuniculi infection in cyclophosphamide-treated rabbits. 


\section{Materials and Methods}

A rabbit isolate of $E$. cuniculi (provided by Dr. O. Ditrich, Institute of Parasitology, Czech Republic) was grown in E-6 cell (Vero green monkey kidney cells) to provide spores. The cells were cultivated in modified RPMI 1640 medium supplemented with $5 \%$ foetal calf serum. The parasites used for inoculation were freshly collected from the culture supernatant after centrifugation at 4000 r. p. m. for 15 min., washed by centrifugation in phosphatebuffered saline (PBS), counted on haemocytometer and adjusted to the concentration desired.

Forty White New Zealand rabbits of both sexes (4-months-old; $2.5+0.5 \mathrm{~kg}$ in weight) were serologically-free of $E$. cuniculi infection and used in the experiment. Four groups of ten rabbits each were housed under conventional conditions with free access to water and food. Animals of the first group, designated as $\mathrm{Ec}+\mathrm{Cy}+$, were infected with intraperitoneal injection of $5 \times 10^{7}$ E. cuniculi spores in $1 \mathrm{ml} \mathrm{PBS}$. In order to induce the immunosuppression, this group was treated intraperitoneally with two dosages of $\mathrm{CY}$ once weekly during period of 12 weeks. First CY dosage $50 \mathrm{mg}$ $/ \mathrm{kg}$ was applied on day 14 after $E$. cuniculi administration and then $15 \mathrm{mg} / \mathrm{kg} \mathrm{CY}$ once a week for period of 12 weeks.

Control groups designated as $\mathrm{Ec}+\mathrm{Cy}$ - and $\mathrm{Ec}-\mathrm{Cy}+$ served as positive control and were treated as follows: group $\mathrm{Ec}+\mathrm{Cy}$ - was. infected i.p. with $5 \times 10^{7} \mathrm{E}$. cuniculi spores, group Ec-Cy+ was treated only with $\mathrm{CY}$ in the same manner as group A. No treatment was done in $\mathrm{Ec}-\mathrm{Cy}$ - which served as negative control. Rabbits of $\mathrm{Ec}+\mathrm{Cy}+$ and $\mathrm{Ec}+\mathrm{Cy}$ - group were kept individually and separately from others in steel cages. The animals were killed by exsanguination in week 12 after the first application of $C Y$.

The indirect immunofluorescence antibody test (IFAT) was used to determine specific anti-E. cuniculi antibodies. The method was performed as detailed by Chalu pský et al. (1973). Briefly, serological reactions were carried out on E. cuniculi covered slides. Slides were incubated for $30 \mathrm{~min}$. at $37^{\circ} \mathrm{C}$ with serially diluted rabbit sera within a moist chamber. They were then incubated with swine anti-rabbit immunoglobulin conjugated by fluorescein-isotiocyanate (SEVAC, Praha) of 1:160 dilution. Dry slides were counter-stained with Evans blue and mounted in buffered glycerine.

CY-induced immunosuppression was estimated by means of white blood cell count. The blood samples were firstly taken two weeks after the primary CY treatment and later biweekly from the marginal aural vein and placed in Turk's solution. The cells were then counted in hemocytometer.

The statistical evaluation of the results was done by one way analysis of variance (ANOVA) with the Bonferroni multiple-comparison post-hoc test.

During necropsy, tissue samples were collected from brain, heart, liver, lung, trachea, urinary bladder, and spleen, and fixed in $10 \%$ buffered formalin. The material was routinely processed for paraffin embedding. Five $\mu \mathrm{m}$ thick sections were stained with haematoxylin-eosin, Giemsa, and van Gieson stain as well. Reactions were classified as follows:

Lymphoplasmacytic - generally characterised by small foci or larger coalescent areas, consisting dense accumulations of lymphocyte and plasmacyte. This type of lesion rarely contained granulomatous component. No epithelioid cells were present and activated macrophages were occasionally found.

Granulomatous - nodular lesions, always containing numerous epithelioid cells or giant multinucleated cells. Epithelioid cells, giant cells, lymphocytes, occasionally eosinophils and neutrophils were included in varying number.

Fibrotic - proliferation of fibrous tissue included fibrocytes, lymphocytes but no significant numbers macrophages and plasma cells.

Other - different type lesions as above mentioned e.g. liver steatosis, catarnhal enteritis and bronchopneumonia as well.

\section{Results}

Animals of groups $\mathrm{Ec}+\mathrm{Cy}+$ and $\mathrm{Ec}+\mathrm{Cy}$ - were IFAT-seropositive in titre 1:64 and higher, while the groups Ec-Cy+ and Ec-Cy-were seronegative.

The necropsy of $\mathrm{Ec}+\mathrm{Cy}+$ group showed small white pinpoint spots on the kidney surface, severe enlarged brownish-yellow livers, and mild splenomegaly. A small volume of straw coloured liquid was found in the abdominal cavity. Rabbits of Ec+Cy-group displayed middle hepatomegaly and, splenomegaly. Massive hepatomegaly and steatosis of the liver were the most significant findings in Ec-Cy+group. Two rabbits of Ec-Cy-group had acute catarrhal bronchopneumonia and enteritis.

Histopathological changes were found in both $\mathrm{Ec}+\mathrm{Cy}+$ and $\mathrm{Ec}+\mathrm{Cy}-$ in the brain, the liver, the kidney and lungs as well (Tab. 1). The animals of Ec+Cy+ group have noted granulomatous lesion in the brain, liver and lungs. Granulomas were distributed in white and grey matter of brain consisting of epithelioid cells, lymphocyte and glial cells as well (Plate IV., Fig.1). They were mainly associated with brain vessels. Perivascular lymphocyte cuffs were also seen in brain. Liver granulomas randomly scattered among the steatotic hepatocyte cords contained 
Table 1

Pathomorphological response to $E$. cuniculi infection in cyclophosphamide-treated rabbits

\begin{tabular}{|c|c|c|c|c|c|c|c|c|c|}
\hline \multirow{2}{*}{$\begin{array}{l}E c+C y+ \\
\text { group }\end{array}$} & \multicolumn{4}{|c|}{ Lesions } & \multirow{2}{*}{$\begin{array}{l}\text { Ec+Cy- } \\
\text { group }\end{array}$} & \multicolumn{4}{|c|}{ Lesions } \\
\hline & liver & kidney & brain & lungs & & liver & kidney & brain & lungs \\
\hline 1 & $H, S, \mathbf{G}$ & $F$ & $\bar{G}$ & $A H, \mathbf{G}$ & 1 & $H, \mathbf{I}$ & $I N, \mathbf{I}$ & - & $A H, \mathbf{I}$ \\
\hline 2 & $H, \mathbf{G}$ & - & G & G & 2 & $H, \mathbf{I}$ & & - & - \\
\hline 3 & $H, \mathbf{I}$ & - & G & G & 3 & $H, \mathbf{I}$ & $I N, \mathbf{I}$ & I & $A H, \mathbf{I}$ \\
\hline 4 & $H, S, \mathbf{G}$ & $F$ & - & - & 4 & - & - & - & - \\
\hline 5 & $H, S, \mathbf{G}$ & $F$ & $\mathbf{G}$ & - & 5 & $H, \mathbf{I}$ & $I N, \mathbf{I}$ & I & - \\
\hline 6 & $H, \mathbf{G}$ & $F$ & - & $A H$ & 6 & $H$ & - & $I$ & $A H, \mathbf{I}$ \\
\hline 7 & $H, S, \mathbf{G}$ & $F$ & - & $\mathbf{G}$ & 7 & $H, \mathrm{I}$ & - & - & - \\
\hline 8 & $H, S, \mathbf{G}$ & - & G & G & 8 & - & $I N, \mathbf{I}$ & - & - \\
\hline 9 & $\mathrm{H}, \mathrm{S}, \mathrm{I}$ & - & $\mathbf{G}$ & $\mathbf{G}$ & 9 & $\mathrm{H}, \mathrm{I}$ & - & $I$ & $\mathrm{AH}$ \\
\hline 10 & $\mathrm{H}, \mathrm{I}$ & $\mathrm{F}$ & G & - & 10 & - & IN, I & I & - \\
\hline
\end{tabular}

$E c+C y+$ group - rabbits $E$. cuniculi infected and cyclophosphamide-immunosuppressed;

$E C+C y$-group $-E$. cuniculi-infected rabbits without cyclophosphamide-immunosuppression

$H$-hepatomegaly; $S$ - liver steatosis; $F$-fibrosis; $I N$ - interstitial nephritis; $A H$-active hyperaemia $\mathbf{G}$ - granulomas;

I-lymphoplasmacytic infiltration; - no lesions

a large number of eosinophils (Plate IV. Fig. 2, Plate V., Fig. 3). Nodular lesions were observed within the lung parenchyma and adjacent to the bronchi ( Plate V., Fig. 4). The kidney showed a growth of granulation tissue strips from the cortex to the medulla (Plate VI., Fig. 5).

In control group with encephalitozoonosis $(\mathrm{Ec}+\mathrm{Cy}-)$, the organs examined showed foci lymphocyte infiltration with an admixture of only a few neutrophils, eosinophils, and the occasional occurrence of macrophages in the parenchyma. The liver parenchyma in the cyclophosphamide-treated control animals $(\mathrm{Ec}-\mathrm{Cy}+)$ showed massive swelling and steatosis of hepatocytes. In this group, diffuse lymphocyte inflammatory reactions in the lungs were seen. The negative controls (Ec-Cy-) did not develop lesions, excluding of two rabbits with acute catarrhal enteritis and bronchopneumonia.

Fig. 6 summarises the immunosuppressive effect of cyclophosphamide on peripheral white blood cells.

Fig. 6

Changes in white blood cell counts in cyclophosphamide-treated rabbits with encephalitozoonosis

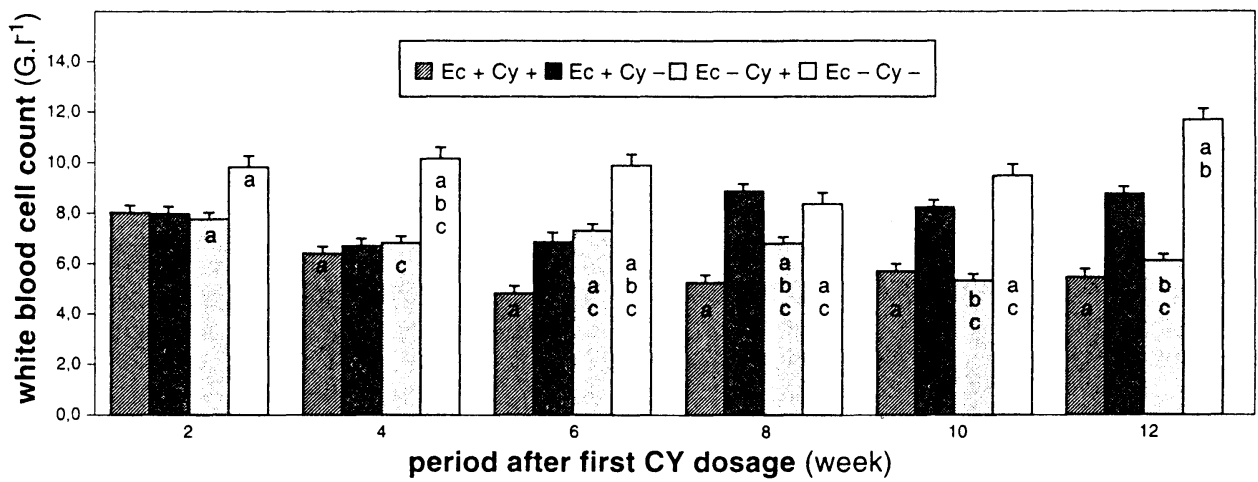

Values are means \pm S.E.M. Same superscript means significantly different groups $(p<0,05)$ within the same week. Ec+Cy-rabbits with $E$. cuniculi and cyclophosphamide; $\mathrm{Ec}+\mathrm{Cy}$-rabbits with $\mathrm{E}$. cuniculi; $\mathrm{Ec}-\mathrm{Cy}+$ rabbits with cyclophosphamide; $\mathrm{Ec}-\mathrm{Cy}-\mathrm{rabbits}$ without $E$. cuniculi and cyclophosphamide. 


\section{Discussion}

The group of rabbits infected with E. cuniculi $(\mathrm{Ec}+\mathrm{Cy}-)$ developed mainly lymphoplasmacytic lesions in the brain and liver, while kidney showed fibrosis. Our finding is similar to the spontaneous oral infection that frequently produces lymphocyte infiltration in organs and where fibrosis is frequently seen in the kidney (Nast et al. 1996; Levkut et al. 1993). The experimental intravenous route of infection tends to give rise to lesions in the kidney, brain and lung (Cox et al. 1979). On the other hand, the liver is most vulnerable target of infection in rabbits administered with $E$. cuniculi per rectum (Fuente alba et al. 1992).

In immunocompetent hosts, lesion formation occurs, but infection is latent and reactivation is prevented (Cox et al. 1979). In immunosuppressed animals and people E. cuniculi infection is associated with a massive spread of parasites, forming disseminated microsporidiosis (Koudela et al. 1993). Moreover, bovine leukaemia virus-induced immunosuppression in rabbits spontaneously infected with $E$. cuniculi has led to the formation of granulomas within subcutaneous tissue (Levkut et al. 1997a).

Granulomatous lesions in immunosuppressed rabbits with encephalitozoonosis $(\mathrm{Ec}+\mathrm{Cy}+)$ were particularly abundant and contained numerous epithelioid cells and giant cell syncytia. Granulomas are known as a nodular or tumour-like masses of granulomatous inflammation (Levkut et al. 1997b) in which defining element is mononuclear phagocyte - macrophage (Wheater et al. 1991). The activated macrophages are known to play an important role in the expression of acquired immunity to $E$. cuniculi (Heřmánek et al. 1993). Murine peritoneal macrophages activated with the lipopolysaccharide of Escherichia coli and INF- $\gamma$ inhibited parasite multiplication within tissue culture (Didier and Shadduck 1994).

Generally, mononuclear phagocytes undergo phenotype and function changes when they are activated, forming multinucleated giant cell and epithelioid cells. Functionally, epithelioid cells have been shown to produce interleukins and angiotensin-converting enzyme, but they lack phagocytic activity (Gordon et al. 1988). They commonly fuse to form syncytia which are known as multinucleated giant cells. Formation of multinucleated giant cells appears to be induced by T-cell-derived cytokines such as IL-4, IL-3 (Lee et al. 1993) and INF- $\gamma$ (Most et al. 1990), but some recent results suggest that parasite load induces fusogenic mechanism in lymphocyte-independent way (Ha n a no et al. 1996). From our results seems that in $\mathrm{Ec}+\mathrm{Cy}+$ rabbits the formation of multinucleated giant cells occurs despite alteration of immune system.

Liver granulomas in $\mathrm{Ec}+\mathrm{Cy}+$ contained lymphocytes and a rich infiltrate of eosinophils. Granuloma formation is a T-dependent and cytokine-mediated reaction in parasitic disease (Chensue et al. 1995). Specific T cell subsets produce different arrays of cytokines. T cells expressing CD4 have been classified, based upon cytokine profile into two major subsets referred to as Th1 and Th2. Th1 type cells produce gamma interferon (INF- $\gamma$ ) and interleukin 2 (IL-2), which are particularly important in the activation of both T cell and macrophage (Coffman and Mosman n 1991). In contrast, Th2 cells produce IL-4, IL-5, IL-6 and IL-10 leading to the generation of humoral immune response and down-regulation of Th1 response (Pearce et al. 1991). Th2 dominant response seems to dictate a florid, eosinophil rich cellular response (Chensue et al. 1993).

The intact thymus is required to prevent lethal disease (Schmidt and Shadduck 1984). Previous studies demonstrated that cell-mediated immune response, including peripheral leukocyte numbers, can be altered by the low and repeated doses of CY (Calabrese et al. 1996). The dose-related decrease in both activity and number of B and T lymphocytes has been observed (Mitusoka et. al. 1979). 
As noted previously, E. cuniculi infection is controlled by the regulatory function of $\mathrm{T}$ lymphocytes. In contrast, $\mathrm{CY}$ affects $\mathrm{T}$ cell population. Concurrent infections with E. cuniculi and human immunodeficiency virus or feline immunodeficiency virus may result in immunosuppression related to CD4+ or CD8+ T cell subpopulation (Lin et al. 1992; Albrecht 1996). Further studies are needed to establish possible association between CY use and the activation of encephalitozoonosis in domestic animals.

The results described show that low and repeated dosage of CY can modify the pathomorphological response to E. cuniculi. We assume that further definition of cell subset mediated formation of lesion in immunosuppressive therapy will lead to a better understanding of the immunological processes in immunocompromised host in encephalitozoonosis.

\section{Patologicko-morfologická odpoved králikov na infekciu E. cuniculi po podaní cyklofosfamidu}

Mikrosporídie sú príčinou oportúnnych infekcií u imunosupresovaných zvierat a človeka. Pre sledovanie hostiteIsko-parazitárnej interakcie sme použili novozélandské biele králiky s encefalitozoonózou ošetrené cyclofosfamidom. Králiky boli infikované intraperitoneálne dávkou $5 \times 10^{7}$ spór králičieho izolátu E. cuniculi. Imunosupresia u králikov bola vyvolaná intraperitoneálnou jednorázovou injekciou $50 \mathrm{mg} / \mathrm{kg}$ cyklofosfamidu 14 dní po vyvolaní experimentálnej encefalitozoonózy a následne dávkou $15 \mathrm{mg} / \mathrm{kg}$ v týždňových intervaloch. Králiky boli utratené v dvanástom týždni od prvej aplikácie cyklofosfamidu.

Patologicko-anatomickým vyšetrením imunosupresovaných králikov s encefalitozoonózou sa zistili zápalové zmeny granulomatózneho typu. U imunokompetentných králikov s encefalitozoonózou sa pozorovali zápalové zmeny lymfocyto-plazmocytárneho typu. Ukazuje sa, že cyklofosfamid možno pokladat za imunopatologický faktor, ktorý modifikuje morfologickú odpoved králikov na infekciu E. cuniculi.

\section{Acknowledgements}

We thank Mrs. Maceková and Dr. Čižmárová for their excellent technical assistance, and Mr. J. Allen for language correction of manuscript. This work was supported by the Scientific Grant Agency of Slovak Ministry of Education of Slovak Republic and Slovak Academy of Sciences (grant no. 1/4223/97).

\section{References}

ALBRECHT, H. 1997: Redefining AIDS: Towards a modification of the current AIDS case definition. Clin. Infect. Dis. 24: 64-74

CALABRESE, K. S., LAGRANGE, P., Da COSTA, S. C. G. 1996: Chagas'disease: enhancement of systemic inflammatory reaction in cyclophosphamide treated mice. Int. J. Immunopharmac. 18: 505-514

COFFMAN, R. L., MOSMANN, T. R. 1991: CD4+ T-cell subsets: regulation of differentiation and function. Res. Immunol. 142: 7-9

COLVIN. M. 1982: The alkylating agents. In: Pharmacologic principles of cancer treatment. Ed: B. A. Chanber, Saunders Co., Philadelphia, pp. 276-308

COX, P. J., PHILIPS B. J., THOMAS, P. 1975: The enzymatic basis of the selective action of cyclophosphamide. Cancer. Res. 35: 3755-3761

COX, J. C., HAMILTON, R. C., ATTWOOD, H. D. 1979: An investigation of the route and progression of Encephalitozoon cuniculi infection in adult rabbits. J. Protozool. 26: 260-265

DIDIER, E. S., SHADDUCK. J. A. 1994: INF-g and LPS induce murine macrophages to kill Encephalitozoon cuniculi in vitro. J. Euk. Microbiol. 41: 34

FUENTEALBA, I. C.. MAHONEY, N. T., SHADDUCK, J. A., HARVILL, J., WICHER, V.. WICHER, K. 1992: Hepatic lesions in rabbits infected with Encephalitozoon cuniculi administered per rectum. Vet Pathol. 29: $536-540$ 
GORDON, S., KESHAV, S., CHUNG, L.P. 1988: Mononuclear phagocytes: tissue distribution and functional heterogenity. Curr. Opin. Immunol. 1: 26-35

HANANO, R., REIFENBERG, K., KAUFFMAN, S. H. E. 1996: T- and B-lymphocyte-independent formation of alveolar macrophage-derived multinucleated giant cells in murine Pneumocystis carinii pneumonia. Infect. Immunity. 64: 2821-2823

HEŘMÁNEK, J., KOUDELA, B., KUČEROVÁ, Z., DITRICH, O., TRÁVNÍCEKK, J. 1993: Prophylactic and therapeutic immune reconstruction of SCID mice infected with Encephalitozoon cuniculi. Folia Parasitol. 40: 287-291

CHALUPSKÝ, J., VÁVRA, J., BEDRNÍK, P. 1973: Detection of antibodies to Encephalitozoon cuniculi in rabbits by indirect immunofluorescence antibody test. Folia Parasitol. 20: 281-284

CHENSUE, S. W., WARMINGTON, K. S., HERSHEY, S. D., TEREBUH, P. D., OTHMAN, M., KUNKEL, S. L. 1993: Evolving T cell responses in murine schisostomiasis. J. Immunol. 151: 1391-1400

CHENSUE, S. W., WARMINGTON, K. S., LUKACS, N. W., LINCOLN, P. M., BURDICK, M. D., STRIETER, R., M., KUNKEL, S. L. 1995: Monocyte chemotactic protein expression during schisostome egg granuloma formation. Am. J. Pathol. 146: 130-138

KOUDELA, B., VÍTOVEC, J., KUČEROVÁ, Z., DITRICH, O., TRÁVNÍČEK, J. 1993: The severe combined immunodeficient mouse as a model for Encephalitozoon cuniculi microsporidiosis. Folia Parasitol. 40: 279-286

LEE, T. T., MARTIN, F. C., MERRILL, J. E. 1993: Lymphokine induction of rat microglia multinucleated giant cell formation. Glia 8: 51-61

LEVKUT, M., LEŚNIK, F., KORIM, P., DANKOVČÍKOVÁ, Z., TIMKOVÁ, J., BÁLENT, P. 1993: Pathological morphological changes in rabbits infected with the bovine leukaemia virus (BLV). Folia Microbiol. 138: 128

LEVKUT, M., LEŚNIK, F., BÁLENT, P., ZAJAC, V., KORIM, P., SLÁVIKOVÁ, K. 1997a: Bovine leukaemia virus-induced clinical changes of encephalitozoonosis in rabbits. Folia Parasitol. 44: 249-259

LEVKUT, M., LEDECKÝ, V., KOLODZIEYSKI, L., ŠEVČ́fK, A. 1997b: Calcified cystic granuloma in dog. Indian Vet. J. 74: 788-789

LIN, D. S., BOWMAN, D., JACOBSON, R. 1992: Immunological changes in cats with concurrent $T$. gondii and feline immunodeficiency virus infection. J. Clin. Microbiol. 30: 17-24

LYNCH, J. P., Mc CUNE, J. W. 1997: Immunosuppressive and cytotoxic pharmacotherapy for pulmonary disorders. Am. J. Respir. Crit. Care Med. 155: 395-142

MALIK, S. W., MYERS, J. L., DeREME, R. A., SPECKS, U. 1996: Lung toxicity associated with cyclophosphamide use: Two distinct patterns. Am. J. Respir. Crit. Care Med. 154: 1851-1856

MERTENS, R. B., DIDIER, E. S., FISHBEIN, M. C., BERTUCCI, D. C., ROGERS, L. B., ORENSTEIN, J. M. 1997: Encephalitozoon cuniculi microsporidiosis: Infection of the brain, heart, kidneys, trachea, adrenal glands, and urinary bladder in a patient with AIDS. Mod. Pathol. 10: 68-77

MITTSUOKA, A., MORIKAWA, S., MITSUO, B., HARADA, T. 1979: Cyclophosphamide eliminates supressor T-cells in age-associated central regulation of delayed hypersensitivity in mice. J. Exp. Med. 149: 1018-1022

MOST, J., NEUMAYER, H. P., DIETRICH, M. P. 1990: Cytokine-induced generation of multinucleated giant cells in vitro requires interferon- $\gamma$ and expression of LFA-1. Eur. J. Immunol. 20: 1661-1667

NAST, R., MIDDLETON, M., WHELER, C. L. 1996: Generalized encephalitozoonosis in a Jersey wooly rabbit. Can. Vet. J. 37: 303-305

PEARCE, E. J., GASPAR, P., GRZYCH, J. M., LEWIS, F. A., SHER, A. 1991: Downregulation of Th 1 cytokine production accompanies induction of Th2 responses by parasitic helminth, Schisostoma mansoni. J. Exp. Med. 173: $159-166$

SCHMIDT, E. C., SHADDUCK, J. A. 1984: Mechanisms of resistance to the intracellular protozoan Encephalitozoon cuniculi in mice. J. Immunol. 133: 2712-2719

WHEATER, P., BURKITT, P., STEVENS, A., LOWE, J. 1991: Chronic inflammation. In: Basic Histopathology, (2. ed.), Churchill Livingstone, pp. 23-39

WICHER, V., BAUGHN, R. E., FUENTEALBA, C., SHADDUCK, J. A., ABBRUSCATO, F., WICHER, K. 1991: Enteric infection with an obligate intracellular parasite, Encephalitozoon cuniculi, in an experimental model. Infect. Immun. 59: 2225-2231 
Plate IV.

Horváth, M. et al.: Pathomorphological... pp. 35-40

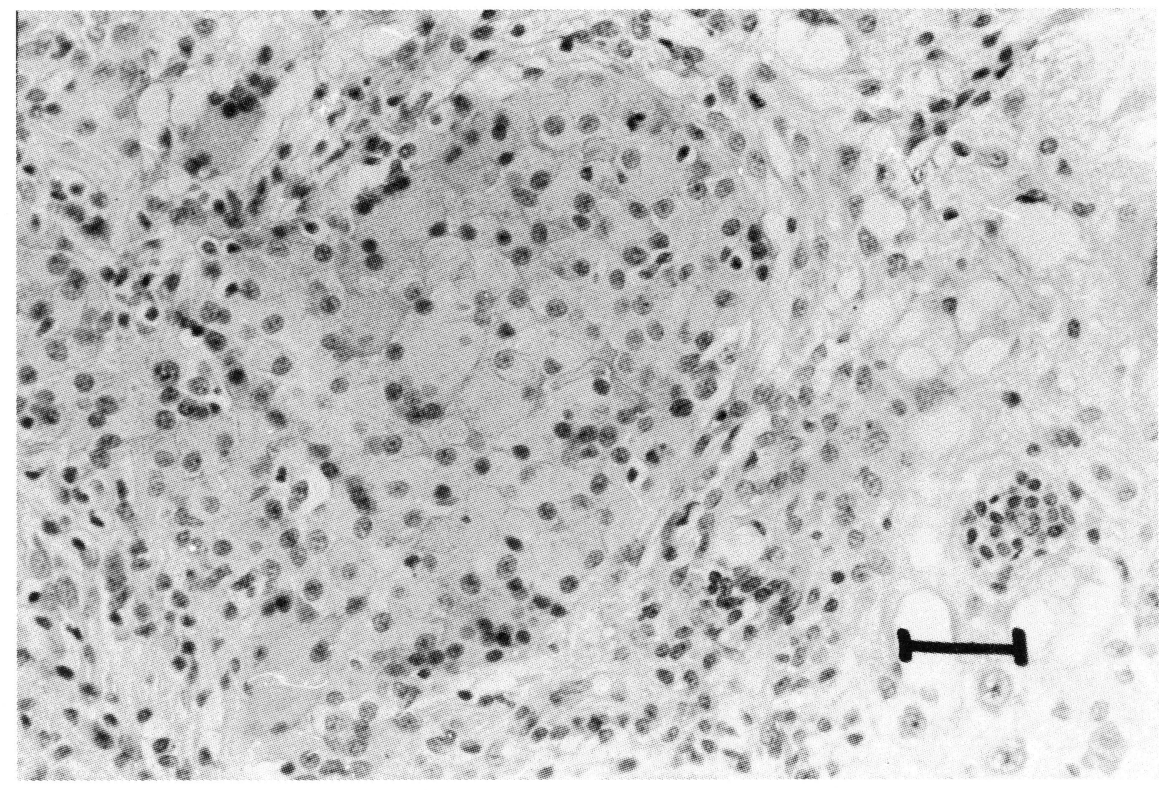

Fig. 1 Brain. The brain granuloma composed of epithelioid cells and multinucleated giant cells (HE, bar $4 \mu \mathrm{m}$ ).

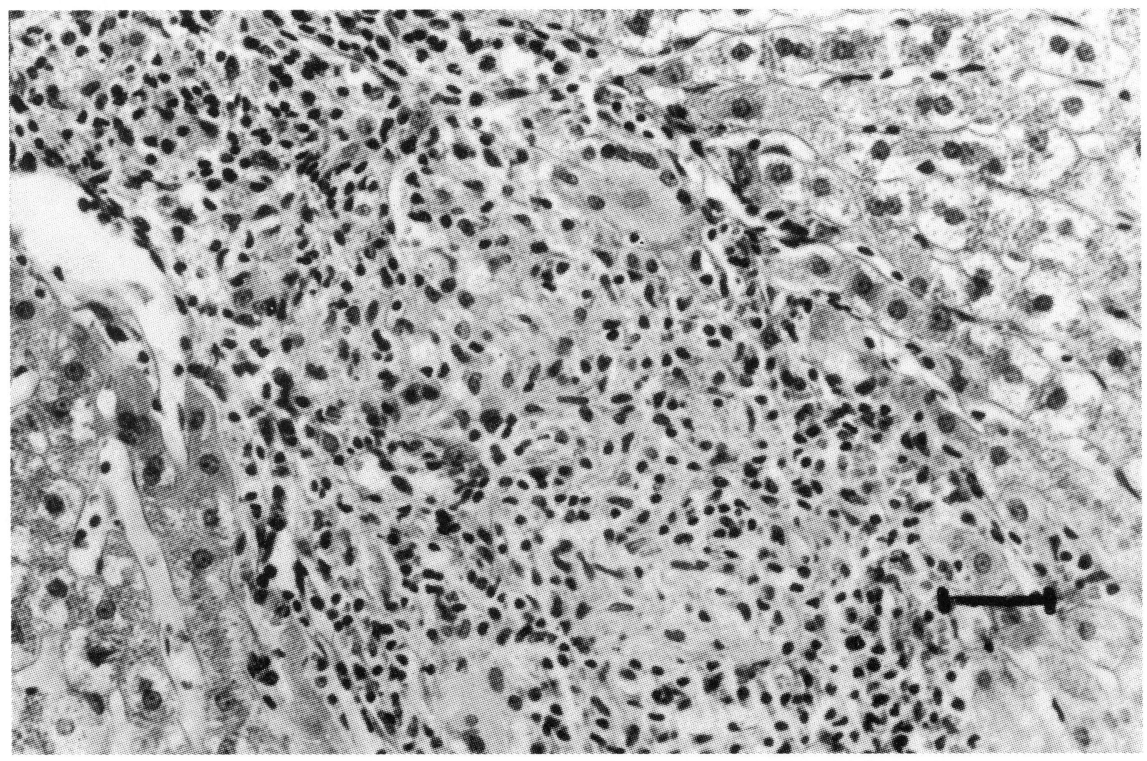

Fig. 2 Liver. Granulomatous hepatitis (HE, bar $4 \mu \mathrm{m}$ ). 
Plate V.

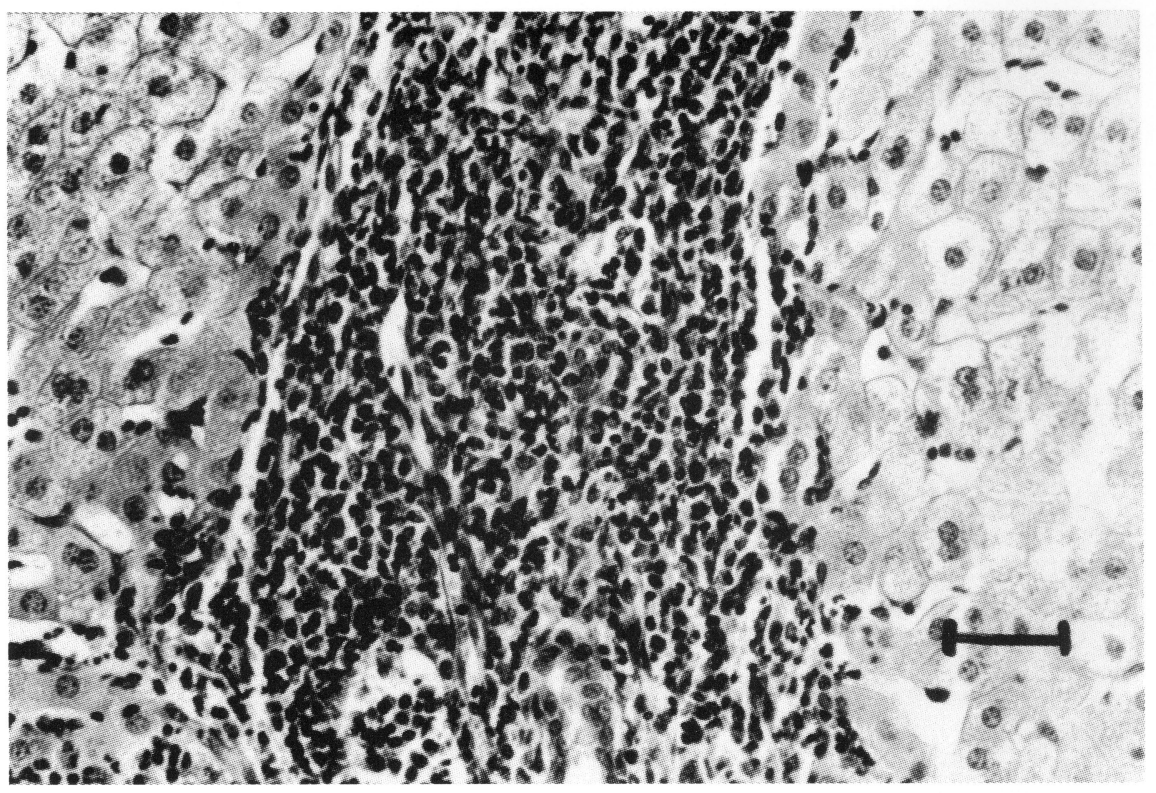

Fig 3 Liver. The rim of mononuclear cells in the portobiliar area (HE, bar $4 \mu \mathrm{m}$ ).

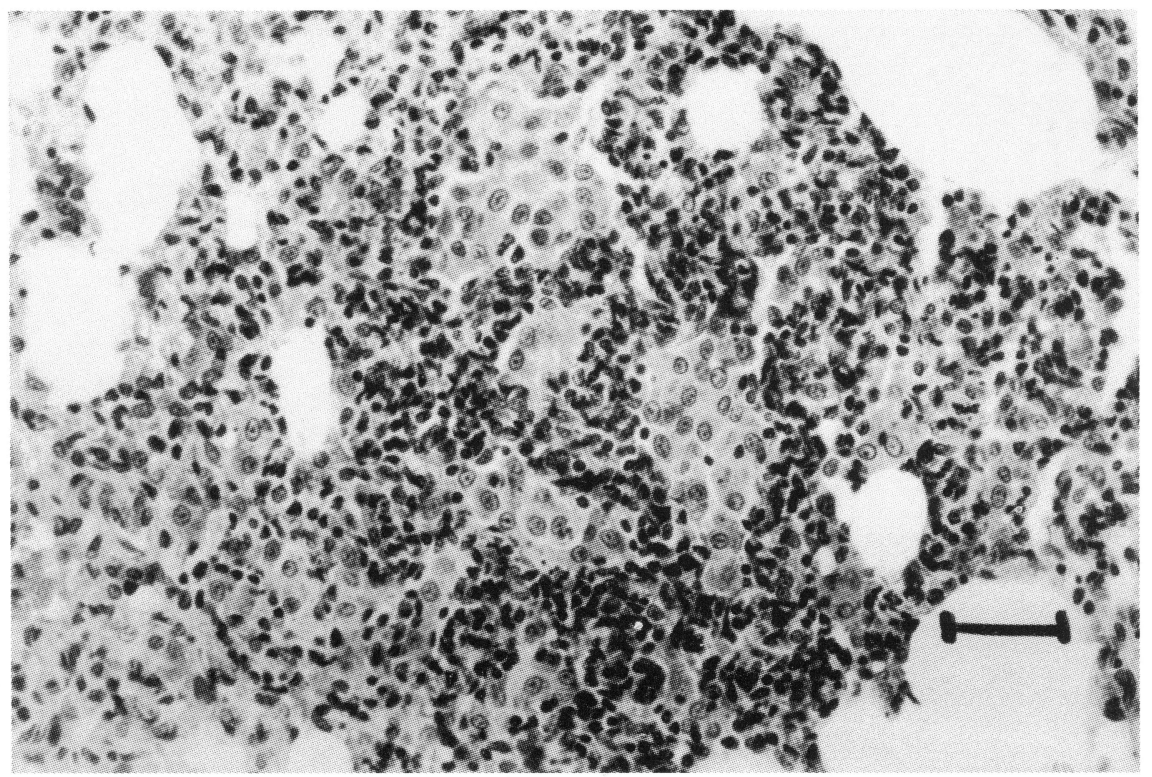

Fig. 4 Lung. Epithelioid granuloma (HE, bar $4 \mu \mathrm{m})$. 


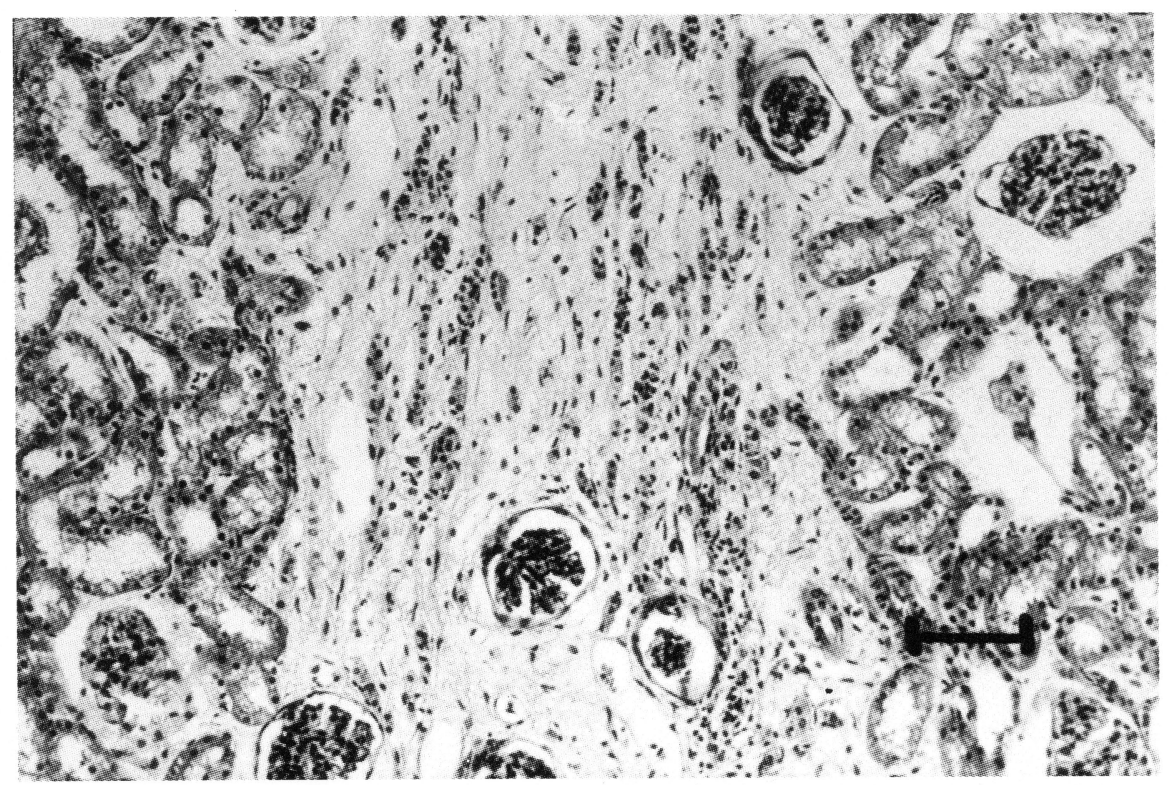

Fig 5. Kidney. Fibrosis - strip of fibrous tissue (HE, bar $4 \mu \mathrm{m}$ ). 